Supporting Information

\title{
Toward High-Capacity Battery Anode Materials: Chemistry and Mechanics Intertwined
}

Matthew T. McDowell1, 2*, Francisco Javier Quintero Cortes ${ }^{2}$, Akila C. Thenuwara1, John A. Lewis $^{2}$

${ }^{1}$ George W. Woodruff School of Mechanical Engineering, Georgia Institute of Technology, Atlanta, GA, USA

${ }^{2}$ School of Materials Science and Engineering, Georgia Institute of Technology, Atlanta, GA, USA

*Corresponding Author: mattmcdowell@gatech.edu 


\section{Details regarding energy calculations in Figure 1 of the main text.}

The energy density and specific energy calculations in the main text considered the mass and volume of all components of the cell stack, as indicated in Fig. S1 and detailed in this section.

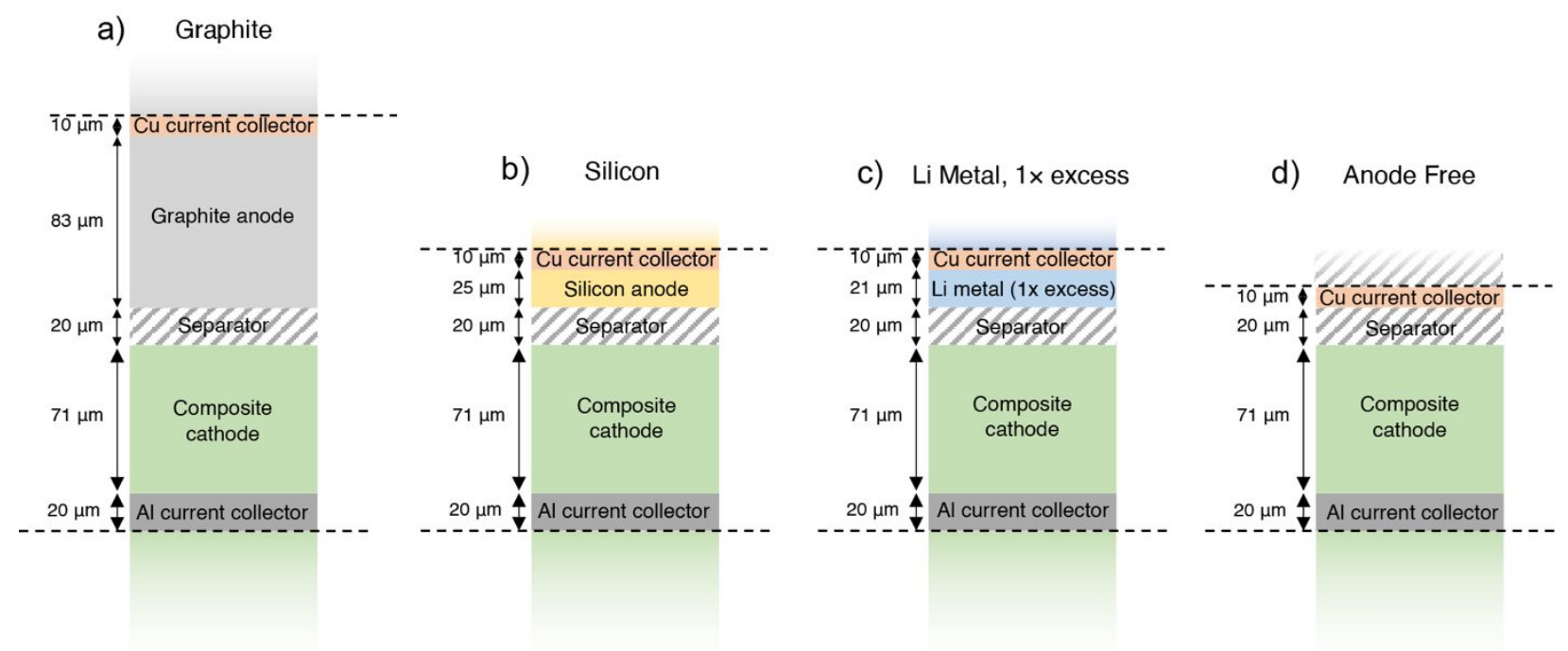

Figure S1. Cell stacks used to calculate the energy density and specific energy in Fig. 1 in the main text. (a) Graphite anode, (b) silicon anode, (c) Li metal anode (1× excess), (d) anode-free.

The paragraphs below provide details on each of the materials and metrics chosen for modeling the energy density and specific energy. We note that many of the values chosen are typical and could be altered in various battery formulations; these particular values are chosen here for consistency in comparison among the anode materials. Some of these values are from Ref. 1.

The following process was used to analyze each electrode. First, the composite density of the electrode, which accounts for both the active material and additives, was calculated based on a weighted sum of the densities for each component. The composite density and porosity of the

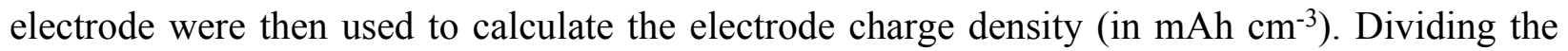
assumed areal capacity for the electrode by the electrode charge density yielded the electrode thickness required. Subsequently, the areal mass loading of the electrode (in $\mathrm{g} \mathrm{cm}^{-2}$ ) was calculated by multiplying the electrode thickness by the total assembled electrode density, which factors in both the composite density and the liquid electrolyte filling the electrode pores. In the case of the 
anode-free lithium metal cell, the electrode thickness and areal mass loading were assumed to be zero since no lithium metal would initially be present.

The specific energy and energy density for each cell configuration were then calculated as follows. The specific energy (in $\mathrm{Wh} \mathrm{kg}^{-1}$ ) for a configuration was calculated by first summing the areal mass loadings for all components in the stack. This sum included the cathode, anode (except for the anode-free design), separator, $\mathrm{Al}$ current collector, and $\mathrm{Cu}$ current collector. Then, the product of the average cell voltage and areal capacity was divided by the total areal mass loading of the

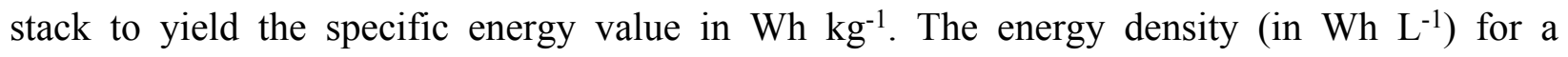
configuration was calculated similarly. However, the product of average cell voltage and areal capacity was instead divided by the total thickness of the stack to yield a value in $\mathrm{Wh} \mathrm{L}^{-1}$.

The resulting values from this analysis are presented below and in Tables S1-S3. All assumed values for different parameters are also included.

Composite cathode. We chose to use $\mathrm{LiNi}_{0.8} \mathrm{Co}_{0.15} \mathrm{Al}_{0.05} \mathrm{O}_{2}$ (NCA) as a prototypical intercalation cathode material. The density is $4.6 \mathrm{~g} \mathrm{~cm}^{-3}$, the specific capacity is $190 \mathrm{mAh} \mathrm{g}^{-1}$, and the average potential during discharge is $3.7 \mathrm{~V}$ vs. $\mathrm{Li}^{-\mathrm{Li}^{+}}$. An areal capacity of $4.0 \mathrm{mAh} \mathrm{cm}{ }^{-2}$ and an assumed $30 \%$ porosity of the electrode correspond to a $71 \mu \mathrm{m}$ thickness. The weight ratio of NCA/binder/conductive additive was assumed to be $95 / 2.5 / 2.5$.

Graphite anode. The density used for graphite is $2.2 \mathrm{~g} \mathrm{~cm}^{-3}$, the specific capacity is $372 \mathrm{mAh} \mathrm{g}^{-1}$, and the average potential during cell discharge is $0.1 \mathrm{~V}$ vs. $\mathrm{Li}^{2} / \mathrm{Li}^{+}$. An N/P ratio of 1.1 was used, for a total anode capacity of $4.4 \mathrm{mAh} \mathrm{cm}^{-2} .30 \%$ porosity was assumed, for a total thickness of 83 $\mu \mathrm{m}$. The weight ratio of graphite/binder/conductive additive was assumed to be 95/2.5/2.5.

Silicon anode. The density used for silicon is $2.32 \mathrm{~g} \mathrm{~cm}^{-3}$. The specific capacity used for silicon was $1636 \mathrm{mAh} \mathrm{g}^{-1}$, which assumes that a pure silicon electrode will only be partially lithiated. The average potential during cell discharge is $0.4 \mathrm{~V} \mathrm{vs} \mathrm{Li} / \mathrm{Li}^{+}$. An areal capacity of $4.4 \mathrm{mAh} \mathrm{cm}{ }^{-2}$ $(\mathrm{N} / \mathrm{P}=1.1)$ and $50 \%$ porosity was assumed, which corresponds to a thickness of $25 \mu \mathrm{m}$ in the delithiated state. Note that this electrode will expand significantly upon lithiation, which is not 
accounted for in these calculations. The weight ratio of Si/binder/conductive additive was assumed to be $95 / 2.5 / 2.5$.

Lithium anode, $1 \times$ excess. The density used for $\mathrm{Li}$ is $0.53 \mathrm{~g} \mathrm{~cm}^{-3}$. " $1 \times$ excess" denotes that a quantity of lithium metal is used at the anode that is 1.1 times that of the $\mathrm{Li}^{+}$capacity contained within the NCA cathode. This corresponds to a thickness of $21 \mu \mathrm{m}$. The average potential during cell discharge is $0.0 \mathrm{~V}$ vs. $\mathrm{Li} / \mathrm{Li}^{+}$. The theoretical specific capacity of lithium was used (3861 mAh $\left.\mathrm{g}^{-1}\right)$. The volume increase during lithium deposition was not accounted for in the calculations.

Anode-free. In this case, no anode material is used, and it is assumed that lithium metal will be directly deposited from the cathode, with all of the $\mathrm{Li}^{+}$ions in the cathode being cycled.

Current collectors and separator. An aluminum current collector was used in contact with the cathode with a $20 \mu \mathrm{m}$ thickness. The density of $\mathrm{Al}$ is $2.7 \mathrm{~g} \mathrm{~cm}^{-3}$. A copper current collector was used in contact with the anode with a $10 \mu \mathrm{m}$ thickness. The density of $\mathrm{Cu}$ is $8.96 \mathrm{~g} \mathrm{~cm}^{-3}$. A polypropylene separator with thickness $20 \mu \mathrm{m}$, density $0.92 \mathrm{~g} \mathrm{~cm}^{-3}$, and porosity of $40 \%$ was used. The densities for the binder, conductive additive, and electrolyte were assumed to be $1.8 \mathrm{~g} \mathrm{~cm}^{-3}$, $0.16 \mathrm{~g} \mathrm{~cm}^{-3}$, and $1.3 \mathrm{~g} \mathrm{~cm}^{-3}$, respectively.

Table S1. Properties of electrodes used in analysis.

\begin{tabular}{|c|c|c|c|c|c|c|c|c|c|}
\hline Electrode Material & $\begin{array}{c}\text { Areal Capacity } \\
\text { (Assumed) }\left[\mathrm{mAh} / \mathrm{cm}^{2}\right]\end{array}$ & $\begin{array}{c}\text { Specific Capacity } \\
{[\mathrm{mAh} / \mathrm{g}]}\end{array}$ & Porosity [-] & $\begin{array}{l}\text { Density } \\
{\left[\mathrm{g} / \mathrm{cm}^{3}\right]}\end{array}$ & $\begin{array}{c}\text { Composite } \\
\text { Density }\left[\mathrm{g} / \mathrm{cm}^{3}\right]\end{array}$ & $\begin{array}{l}\text { Electrode Density (w/ } \\
\text { Electrolyte) }\left[\mathrm{g}^{\mathrm{c}} \mathrm{\textrm {cm } ^ { 3 } ]}\right.\end{array}$ & $\begin{array}{l}\text { Electrode Charge } \\
\left.\text { Density [mAh/cm } / \mathrm{cm}^{3}\right]\end{array}$ & $\begin{array}{c}\text { Electrode } \\
\text { Thickness [cm] }\end{array}$ & $\begin{array}{c}\text { Areal Loading } \\
{\left[\mathrm{g}_{\mathrm{g}} / \mathrm{cm}^{2}\right]}\end{array}$ \\
\hline NCA & 4.0 & 190 & 0.3 & 4.6 & 4.42 & 3.48 & 558 & 0.00716 & 0.0250 \\
\hline Graphite & 4.4 & 372 & 0.3 & 2.2 & 2.14 & 1.89 & 529 & 0.00832 & 0.0157 \\
\hline Silicon & 4.4 & 1636 & 0.5 & 2.32 & 2.25 & 1.78 & 1751 & 0.00251 & 0.0045 \\
\hline Lithium (1x Excess) & 4.4 & 3861 & - & 0.53 & 0.53 & 0.53 & 2046 & 0.00215 & 0.0011 \\
\hline Lithium (Anodeless) & 4.0 & 3861 & - & 0.53 & 0.53 & 0.53 & 2046 & - & - \\
\hline
\end{tabular}

Table S2. Properties of other components within cells.

\begin{tabular}{|r|c|c|c|c|}
\cline { 2 - 5 } \multicolumn{1}{c|}{} & $\begin{array}{c}\text { Weight } \\
\text { Additional Materials }\end{array}$ & $\begin{array}{c}\text { Density } \\
\text { Percent }[-]\end{array}$ & $\begin{array}{c}\text { Thickness } \\
{\left[\mathrm{g}^{\mathrm{c}} \mathrm{cm}^{3}\right]}\end{array}$ & $\begin{array}{c}\text { Areal Mass } \\
{[\mathrm{cm}]}\end{array}$ \\
\hline Binder & 0.025 & 1.8 & - & - \\
\hline Conductive Additive & 0.025 & 0.16 & - & - \\
\hline Electrolyte & - & 1.3 & - & - \\
\hline Aluminum cc & - & 2.7 & 0.002 & 0.0054 \\
\hline Copper cc & - & 8.96 & 0.001 & 0.00896 \\
\hline Separator & - & 1.07 & 0.002 & 0.00214 \\
\hline
\end{tabular}

Table S3. Specific energy and energy density of full cell combinations.

\begin{tabular}{|r|c|c|c|c|c|}
\cline { 2 - 6 } \multicolumn{1}{c|}{} & $\begin{array}{c}\text { Average Cell } \\
\text { Cell Configuration }\end{array}$ & $\begin{array}{c}\text { Total Thickness } \\
{[\mathrm{cm}]}\end{array}$ & $\begin{array}{c}\text { Total Areal } \\
\left.\text { Mass [g/cm }{ }^{2}\right]\end{array}$ & $\begin{array}{c}\text { Specific Energy } \\
{[\mathrm{Wh} / \mathrm{kg}]}\end{array}$ & $\begin{array}{c}\text { Energy Density } \\
{[\mathrm{Wh} / \mathrm{L}]}\end{array}$ \\
\hline Graphite/NCA & 3.6 & 0.0205 & 0.0571 & 252 & 703 \\
\hline Silicon/NCA & 3.3 & 0.0147 & 0.0459 & 287 & 899 \\
\hline Lithium/NCA (1x excess) & 3.7 & 0.0143 & 0.0426 & 347 & 1034 \\
\hline Anode Free/NCA & 3.7 & 0.0122 & 0.0415 & 357 & 1217 \\
\hline
\end{tabular}




\section{References}

1. E. J. Berg, C. Villevieille, D. Streich, S. Trabesinger, P. Novák, J. Electrochem. Soc. (2015) 162, 14, A2468-A2475. 